\title{
Pyuria in institutionalized elderly subjects
}

\author{
K RODGERS, MD, LE NICOLLE, MD, M MCINTYRE, MD, GKM HARDING, MD, \\ D HOBAN, MD, D MURRAY, MD
}

\begin{abstract}
K Rodgers, LE Nicolle, M Mcintyre, GKM Harding, D Hoban, D MurRay. Pyuria in institutionalized elderly subjects. Can J Infect Dis 1991;2(4):142-146. Two hundred and forty-three urine specimens from 76 elderly institutionalized residents were obtained for urine culture, quantitative leukocyte count and urinalysis. Significant bacteriuria was present in 153 specimens $(63 \%)$, including $33(22 \%)$ with more than one organism. Pyuria (greater than or equal to 10 leukocytes $/ \mathrm{mm}^{3}$ ) was present in 214 specimens (88\%), including $116(97 \%)$ with single organism bacteriuria, $27(82 \%)$ with multiple organism bacteriuria, and $71(80 \%)$ without significant bacteriuria. The leukocyte esterase test had a positive predictive value of $99 \%$ for pyuria but a negative predictive value of only 30\%. The quantitative level of pyuria was associated with the level of proteinuria and inversely with $\mathrm{pH}$. A relatively constant level of pyuria tended to persist over months to years in a given individual if bacteriuria persisted. Pyuria is significantly associated with bacteriuria in the institutionalized elderly, but is also common in the nonbacteriuric. The clinical significance of pyuria requires further assessment.
\end{abstract}

Key Words: Elderly, Pyuria, Urinalysis, Urinary infection

\section{La pyurie et la personne âgée hospitalisée}

RESUME: Deux cent quarante-trois échantillons d'urine recueillis chez 76 personnes âgées hospitalisées ont fait l'objet d'urocultures, de numérations leucocytaires et d'examens des urines. Une bactériurie significative était présente dans 153 (63\%) échantillons, dont 33 (22 $\%)$ à plus d'un organisme. Une pyurie égale ou supérieure à 10 leucocytes par millimètre cube était présente dans 214 (88\%) échantillons, dont $116(97 \%)$ présentaient des bactériuries à un seul germe, 27 (82\%) des bactériuries à germes multiples, et 71 (80\%) étaient sans bactériurie significative. Le dosage des estérases leucocytaires avait une valeur prédictive positive de $99 \%$ pour la pyurie mais une valeur prédictive négative de seulement $30 \%$. La concentration quantitative de pyurie était associée au niveau de protéinurie et inversement au $\mathrm{pH}$. Un niveau relativement constant de pyurie avait tendance à persister sur plusieurs mois et jusqu'à plusieurs années chez un sujet donné si la bactériurie se prolongeait. La pyurie présente une association significative avec la bactériurie chez les personnes âgées hospitalisées, mais elle est aussi courante chez les non-bactériuriques. L'importance clinique de la pyurie requiert qu'on poursuive l'évaluation.

Sections of Geriatric Medicine and Infectious Diseases, Department of Internal Medicine and Department of Medical Microbiology, University of Manitoba; and Deer Lodge Centre, Winnipeg. Manitoba

Correspondence and reprints: Dr K Rodgers, c/o MS675D. Health Sciences Centre, 820 Sherbrook Street, Winnipeg, Manitoba R3S 1R9. Telephone (204) 787-4655

Received for publication August 22, 1990. Accepted October 16, 1990. 
A S MANY AS 30 TO 50\% OF ELDERLY INSTITUTIONALized individuals have persistent bacteriuria (1-4). The prevalence of bacteriuria correlates with the level of functional disability $(3,5,6)$, and is highest in the most disabled. In the absence of a chronic indwelling catheter, bacteriuria is associated with relatively low morbidity, and treatment with antibiotics is followed by early recurrence $(1,2)$. It has been suggested, however, that the presence of pyuria in individuals with bacteriuria is an indicator of infection of the urinary tract rather than 'colonization', and that pyuria is an indication for therapy. The validity of treatment decisions based on the presence or absence of pyuria has not been reported.

This study was undertaken to determine some of the characteristics of pyuria in a group of institutionalized elderly subjects. The association of pyuria with bacteriuria and other urinary characteristics including $\mathrm{pH}$, protein and glucose measurements, type of infecting organism, and the leukocyte esterase test were examined. Some observations on the natural history of pyuria are also reported, including degree of variability in the same individual over time.

\section{PATIENTS AND METHODS}

Patient population: The population studied included 57 males and 19 females, 32\% of the 239 permanent residents of the Deer Lodge Centre, an extended care facility in Winnipeg, Manitoba. The mean age was 80 years (range 50 to 95). All participants had a high level of functional disability. Urine specimens were collected from a convenience sample of residents for a study characterizing some features of asymptomatic bacteriuria in this population. Nursing staff collected specimens from one individual whom they felt had bacteriuria based on a subjective assessment of smell and cloudiness, and from a second individual on the same ward whom they thought did not have infection. Residents with symptomatic bacteriuria characterized by symptoms of dysuria, frequency, urgency, hematuria, acute alteration in continence status, suprapubic discomfort, or signs of epididymo-orchitis or bacteremia, were excluded.

Microbiological and biochemical methods: Urine specimens were obtained by 'clean catch' technique at the first morning void. Patients who were unable to control bladder function and required condom drainage had the first urine voided and leg-bag collected after the application of a clean condom (7). Six individuals with chronic indwelling catheters had specimens collected by aspiration from the catheter port.

Specimens were refrigerated at $4^{\circ} \mathrm{C}$ immedi- ately following collection until transfer to the laboratory. Urine was inoculated quantitatively onto a split plate containing MacConkey agar and blood agar, and incubated at $37^{\circ} \mathrm{C}$ for 24 to $48 \mathrm{~h}$. Quantitation, isolation and identification of organisms was done using standard microbiological methods (8). Routine urinalysis was performed to identify glucose, protein and $\mathrm{pH}$. The leukocyte esterase test was performed using a Chemstrip 6L $\mathrm{R}$ (Mannaheim Co), and the quantitative leukocyte count determined on uncentrifuged urine by the hemocytometer method. For a subset of 89 specimens the quantitative leukocyte count was performed three times on the same specimen to determine variability in the test for the same specimen.

Definitions and analysis: Pyuria was defined as greater than or equal to 10 leukocytes $/ \mathrm{mm}^{3}$ urine $\left(10 \times 10^{6} / \mathrm{L}\right)$. Significant bacteriuria was defined as greater than or equal to $10^{5}$ colony forming units (cfu) of one or more organisms/mL urine (equivalent to $\left.10^{8} \mathrm{cfu} / \mathrm{L}\right)$. For studies of the variability of pyuria in the same specimen or over time, the leukocyte count was expressed as the $\log _{10}$. Statistical analysis used standard hypothesis tests, including the $\chi^{2}$ test for proportions and $t$ test and analysis of variance for comparison of means, and was performed on a personal computer with the Microstat computer package (Ecosoft Inc, Indiana).

\section{RESULTS}

Pyuria: Two hundred and forty-three specimens from 76 individuals were studied. Fifty-four residents had more than one urine specimen collected at intervals from three weeks to 30 months. Bacteriuria was identified in 225 specimens (93\%), but only 153 (63\%) had significant growth. For specimens with significant growth, 120 (49\% of total specimens and $78 \%$ of those with significant growth) had a single organism, while 33 (13\% of total and $22 \%$ of those with significant growth) had more than one organism isolated. For one specimen a quantitative bacterial count was not available.

Two hundred and fourteen specimens (88\%) had greater than or equal to 10 leukocytes $/ \mathrm{mm}^{3}$. These included 70 (29\% of total) with 11 to 100 leukocytes $/ \mathrm{mm}^{3}$; $99(40 \%)$ with 101 to 1000 leukocytes $/ \mathrm{mm}^{3}$; and 45 (19\%) with greater than 1000 leukocytes $/ \mathrm{mm}^{3}$. The mean coefficient of variation for the quantitative leukocyte count was 0.146 for three examinations on the same specimen, indicating approximately 15\% laboratory variation among readings.

Relationship to bacteriuria: One hundred and sixteen of 120 specimens (97\%) with significant 
TABLE 1

The association of urine $\mathrm{pH}$ and protein with level of pyuria in urine specimens from the institutionalized elderly

\begin{tabular}{ccc}
\hline Leukocyte count $/ \mathrm{mm}^{3}$ & $\mathrm{pH}$ & Protein \\
\hline $0-10$ & $6.6 \pm 0.8$ & $0.16 \pm 0.52$ \\
$11-100$ & $7.1 \pm 1.4$ & $0.81 \pm 1.19$ \\
$100-1000$ & $7.0 \pm 1.2$ & $1.34 \pm 1.79$ \\
$>1000$ & $6.7 \pm 1.1$ & $2.10 \pm 1.59$ \\
\hline
\end{tabular}

Values are given as mean $\pm S D$

TABLE 2

Associations of urinalysis variables with cell count and with infecting organism

\begin{tabular}{lccc}
\hline Organism $\left(\geq 10^{5} \mathrm{cfu} / \mathrm{mL}\right)$ & $\mathrm{pH}$ & Protein & $\begin{array}{c}\log _{10} \\
\text { WBC }\end{array}$ \\
\hline Escherichia coll $(\mathrm{n}=33)$ & $6.2 \pm 0.9$ & $0.74 \pm 1.58$ & $2.5 \pm 0.9$ \\
Proteus mirabilis $(\mathrm{n}=31)$ & $8.1 \pm 1.0$ & $2.26 \pm 1.91$ & $2.6 \pm 0.6$ \\
Providencia stuartii $(\mathrm{n}=18)$ & $7.4 \pm 1.2$ & $1.28 \pm 1.56$ & $2.5 \pm 0.7$ \\
Other pure cultures $(n=38)^{*}$ & $7.4 \pm 1.3$ & $2.04 \pm 1.59$ & $2.6 \pm 0.8$ \\
\hline
\end{tabular}

Values given are mean $\pm S D$. "Ten different species are included in this group. cfu Colony forming units; WBC White blood cell count

\section{TABLE 3}

The relationship of $\mathrm{pH}$ to quantitative leukocyte count stratified by infecting organism

\begin{tabular}{lcccc}
\hline & \multicolumn{4}{c}{ Quantitative leukocyte count } \\
& $10-100$ & $100-1000$ & $>1000$ & $P$ \\
\hline $\begin{array}{c}\text { Providencia stuartii } \\
(\mathrm{n}=18)\end{array}$ & $8.4(5)$ & $7.3(7)$ & $6.8(6)$ & $0.04^{*}$ \\
$\begin{array}{c}\text { Proteus mirabilis } \\
(\mathrm{n}=30)\end{array}$ & $8.8(5)$ & $8.3(8)$ & $7.4(7)$ & $0.04^{*}$ \\
$\begin{array}{c}\text { Escherichia coli } \\
(\mathrm{n}=33)\end{array}$ & $6.3(6)$ & $6.2(19)$ & $6.4(8)$ & $0.84^{*}$ \\
\hline Numbers in brackets are numbers of specimens, *Analysis of variance
\end{tabular}

bacteriuria with a single organism, and 27 of 33 multiple organism bacteriuria specimens (82\%), had pyuria. However, 10 of 17 specimens (59\%) with no growth and 61 of $72(85 \%)$ with lower quantitative counts of bacteria also had pyuria. Eighteen of the 243 specimens were collected while the patient was receiving or within seven days following antibiotic treatment for various infections. Eleven of these specimens (61\%) still showed bacteriuria, and 16 (89\%) had pyuria.

Pyuria had a sensitivity of $97 \%$, a specificity of $72 \%$, a positive predictive value of $70 \%$ and a negative predictive value of $83 \%$ for bacteriuria. Conversely, bacteriuria had a sensitivity of $71 \%$, a specificity of $82 \%$, a positive predictive value of $97 \%$, and a negative predictive value of $27 \%$ for pyuria. Thus, only $27 \%$ of specimens with no significant bacterial growth also had less than 10 leukocytes $/ \mu \mathrm{L}$.

Urinalysis variables and infecting organisms: Table 1 shows the observed associations of pyuria with other urinalysis variables. Glycosuria was identified in only eight urine specimens, and no analysis with glycosuria was undertaken. Proteinuria was expressed on a scale of 0 to 6 , representing a range of protein from 0 to more than $3 \mathrm{~g} / \mathrm{L}$. The level of pyuria correlated with the level of proteinuria (analysis of variance $\mathrm{P}<0.001$ ) and urine $\mathrm{pH}(\mathrm{P}=0.009)$. This association remained significant when specimens without pyuria, and thus presumably without bacteriuria, were removed, with higher white cell counts at a lower urine $\mathrm{pH}$.

The most common infecting organisms were Proteus mirabilis, Escherichia coli and Providencia stuartii. When specimens with pure cultures in significant quantities were studied, there was a significant association with both urine $\mathrm{pH}$ (analysis of variance $\mathrm{P}<0.001$ ) and proteinuria (analysis of variance $\mathrm{P}<0.001$ ), and organism isolated (Table 2). The level of pyuria was not significantly associated with the type of organism. As it has been previously reported that leukocytes disintegrate rapidly at elevated $\mathrm{pH}$, the $\mathrm{pH}$ values with specimens stratified by infecting organism and leukocyte count were examined (Table 3). There was an inverse correlation between quantitative leukocyte count and urinary $\mathrm{pH}$ for the urease-producing organisms, but not for $E$ coli.

The level of pyuria may have been influenced by factors specific to the individual subjects studied, particularly if one individual contributed a number of urine specimens to the study. To control for this potential confounding factor, the analysis was repeated using only the first specimen collected from each of the 76 individuals. The results obtained for all associations were similar to those when all 243 urine specimens were examined. The relationships were statistically significant in this 'first specimen group' except for the relationship between the level of pyuria and $\mathrm{pH}$ and protein. For that analysis the trends were consistent with the observed associations for all specimens, but did not reach statistical significance.

Leukocyte esterase test: The leukocyte esterase test was positive $(1+$ or greater) for 153 of 215 specimens $(71 \%)$ with pyuria, and two of $28(7 \%)$ without pyuria. The test was positive for 116 of 153 (76\%) with significant bacteriuria, 32 of 72 (44\%) with low count bacteriuria, and five of 17 (29\%) without bacteriuria.

The positive predictive value of the leukocyte esterase test for pyuria was 99\%. However, when negative, the leukocyte esterase test was associated with the absence of pyuria in only $30 \%$ of specimens. For specimens with pyuria and a negative leukocyte esterase test, 14 had less than or equal to 10 leukocytes $/ \mathrm{mm}^{3}, 31$ had 11 to 100 


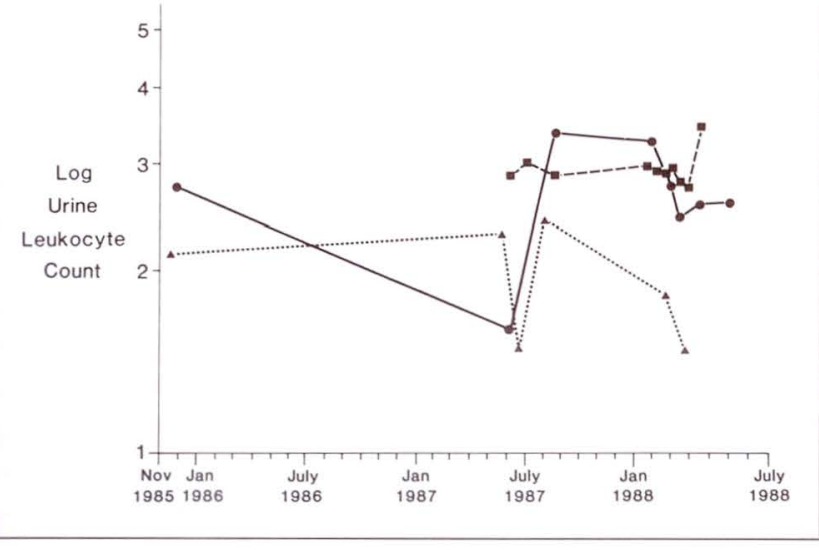

Figure 1) Variation in quantitative urinary leukocyte count with time in three individuals with multiple specimens obtained

leukocytes $/ \mathrm{mm}^{3}, 16$ had 101 to 1000 leukocytes / $\mathrm{mm}^{3}$, and one had over 1000 leukocytes $/ \mathrm{mm}^{3}$.

Variation of pyuria with time: The 54 patients with multiple urine specimens collected over extended times were analyzed to determine the variation in pyuria with time. Figure 1 illustrates three representative individuals. While some fluctuations in the level of pyuria are seen, these tended to be less than one log variation, with the level of pyuria relatively constant over even extended periods. The mean coefficient of variation expressed as the log of the leukocyte count was $0.57 \pm 0.57$ for all individuals. When only pure cultures with significant bacterial growth were examined, the mean coefficient of variation of the quantitative leukocyte count was $0.27 \pm 0.20$. Thus, there may be as much as $57 \%$ of one log variation in the white count of each individual over the study months, with even less variation in individuals with persistent single organism infection.

\section{DISCUSSION}

This study documented a high prevalence of pyuria in an elderly institutionalized population. Urine specimens were not collected from all institutional residents, nor a randomized subset, so the proportion of institutional residents with pyuria cannot be determined. However, the data here show that for a selected group of institutionalized elderly, pyuria was present in most urine specimens. It is virtually universal in individuals with bacteriuria both with and without indwelling catheters, but also common in those without bacteriuria. In addition, the mean absolute leukocyte count in an individual tended to remain relatively constant over time.

Previous studies in ambulatory elderly men and women have also found pyuria to be common $(3,4,6)$, but similar studies from institutionalized populations are not, to the authors' knowledge, available. In previous studies in a small group of elderly men institutionalized in a chronic care facility and women in an acute care facility, both with asymptomatic bacteriuria, the authors observed that $90 \%$ of individuals with bacteriuria had pyuria $(7,9)$. Pyuria was highly predictive for the presence or absence of bacteriuria in elderly asymptomatic ambulatory men (10), but was not a good predictor for bacteriuria in a group of ambulatory women, some of whom were institutionalized (6). These observations reconfirm that pyuria is universal with bacteriuria in the institutionalized elderly and would not, in the absence of symptoms, be an indication for therapy. To the authors' knowledge, no previous studies have observed the persistence of pyuria for extended periods of time.

Residents with bacteriuria with quantitative counts less than $10^{5} \mathrm{cfu} / \mathrm{mL}$ may have either true bacteriuria or contaminated specimens. The proportion with pyuria in this group was similar to that observed for the group with 'significant bacteriuria'. While the observation of pyuria in these specimens is consistent with these low quantitative counts denoting true bacteriuria, it is also possible that conditions which increase the likelihood of bacterial contamination, such as vaginitis in women and urethritis in men, would also be associated with increased likelihood of contamination of voided urine specimens with leukocytes. Thus, the clinical significance of pyuria in this group requires further characterization.

Pyuria was measured using the hemocytometer counting chamber method. The hemocytometer method correlates closely with the leukocyte excretion rate, considered to be the 'gold standard' for quantitating pyuria. Greater than 10 leukocytes $/ \mathrm{mm}^{3}$ has been shown to correlate with greater than 400,000 leukocytes/h determined by the excretion rate (10). The method used most commonly in clinical practice is, however, determination of leukocytes per microscopic high power field in a centrifuged urine specimen. This does not correlate well with the leukocyte excretion rate and is not reproducible due to a number of uncontrolled factors (11). Thus the observations with respect to pyuria in this study are more reliable than those based on standard urinalysis.

When the relationship of pyuria to bacteriuria was examined, the authors found that if bacteria were present in the urine, pyuria was also present in $97 \%$ of specimens. Of specimens with pyuria, $70 \%$ also had bacteriuria. Thus bacteriuria was a better predictor for pyuria than pyuria was for bacteriuria. The absence of bacterial growth in the 
urine was a poor predictor for the absence of leukocytes in the urine, with a negative predictive value of only $27 \%$. In other populations, the leukocyte esterase test has been reported to have a sensitivity of 72 to $97 \%$ (12). The leukocyte esterase test in this population had a sensitivity of $71 \%$ with a positive predictive value for pyuria of $99 \%$ but a negative predictive value of only $30 \%$; specimens with pyuria and negative esterase tests tended, however, to have lower leukocyte counts. Thus, in this population, the leukocyte esterase dipstick method would be a poor screening tool due to the lack of sensitivity.

The level of pyuria is associated with the level of urine protein, with higher amounts of urine protein corresponding to higher leukocyte counts. As well, a trend towards higher levels of pyuria at lower pHs was also noted, which was most apparent when the analysis was stratified by organism and leukocyte level. It has previously been observed that at alkaline $\mathrm{pH}$ leukocytes disintegrate more rapidly, likely explaining the inverse association of $\mathrm{pH}$ and urine leukocytes (13). Despite the variation in urine $\mathrm{pH}$ and protein

ACKNOWLEDGEMENTS: This study was made possible through the support and cooperation of the nursing and laboratory staff at Deer Lodge Centre. Expert secretarial assistance was provided by Brenda Kowalczyk.

\section{REFERENCES}

1. Nicolle LE, Bjornson J, Harding GKM, MacDonell JA. Bacteriuria in elderly institutionalized men. N Engl J Med 1983;309:1420-5.

2. Nicolle LE, Mayhew J, Bryan L. Prospective randomized comparison of therapy and no therapy for asymptomatic bacteriuria in institutionalized elderly women. Am J Med 1987;83:27-33.

3. Heinamaki P, Haavisto M, Mattila K, Rajala S. Urinary characteristics and infection in the very aged. Gerontology 1984;30:403-7.

4. Kaye D. Urinary tract infection in the elderly. Bull N Y Acad Med 1980;50:209-20.

5. Nicolle LE, Henderson E, Bjornson J, et al. The association of bacteriuria with resident characteristics and survival in elderly institutionalized men. Ann Intern Med 1987;106:682-6.

6. Boscia J, Abrutyn E, Levison M, Pitsakis P, Kaye levels with different infecting species, the level of pyuria did not vary with the type of organism. This observation suggests that two opposing factors may be involved: higher urine pHs and thus more leukocyte disintegration, together with an increased inflammatory reaction which is organism dependent, leading to a relatively stable leukocyte count. This observation requires further study.

The significance of the high prevalence of pyuria in institutionalized elderly individuals with asymptomatic bacteriuria is unclear. Previous studies have documented little morbidity and mortality attributable to bacteriuria in this population $(1,2)$. As shown here, pyuria appears to be universal with asymptomatic bacteriuria in elderly institutionalized individuals. One may infer that morbidity and mortality are not influenced by the presence of pyuria, although this requires direct confirmation. Pyuria indicates inflammation in the urinary tract, but it appears that the inflammation remains subclinical and recurs with reinfection post therapy. The causes and significance of pyuria in patients without bacteriuria require further study.

D. Pyuria and asymptomatic bacteriuria in elderly ambulatory women. Ann Intern Med 1989;110:404-5.

7. Nicolle LE, Harding GKM, Kennedy J, McIntyre M, Aoki F, Murray D. Urine specimen collection with external devices for diagnosis of bacteriuria in elderly incontinent men. J Clin Microbiol 1988;26:1115-9.

8. Lennette EH, Balows A, Hausler WJ Jr, Shadomy HJ. Manual of Clinical Microbiology, 4th edn. Washington DC: American Society of Microbiology, 1985.

9. Nicolle LE, Muir P, Harding GKM, Norris M. Localization of urinary tract infection in elderly, institutionalized women with asymptomatic bacteriuria. J Infect Dis 1988;157:65-70.

10. Norman D, Yamamura R, Yoshikawa T. Pyuria: Its predictive value of asymptomatic bacteriuria in ambulatory elderly men. J Urol 1986;135:520-1.

11. Stamm W. Measurement of pyuria and its relation to bacteriuria. Am J Med 1983;75:S53-7.

12. Pels RV, Bor DH, Woolhandler S, Himmelstein DU, Lawrence RS. Dipstick urinalysis screening of asymptomatic adults for urinary tract disorder. II. Bacteriuria. JAMA 1989;262:1221-4.

13. Pollock HM. Laboratory techniques for detection of urinary tract infection and assessment of value. Am J Med 1983;75:S79-84. 


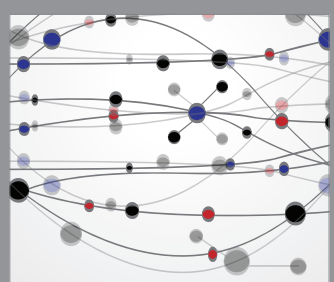

The Scientific World Journal
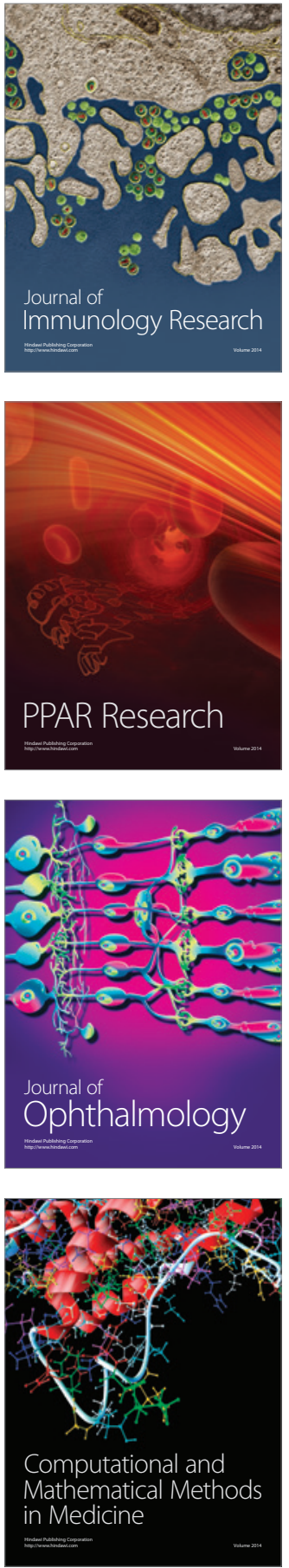

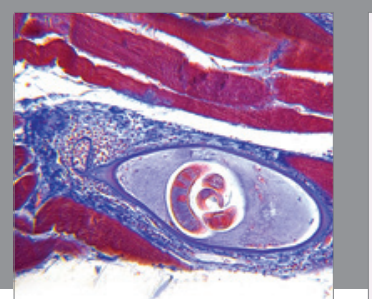

Gastroenterology Research and Practice

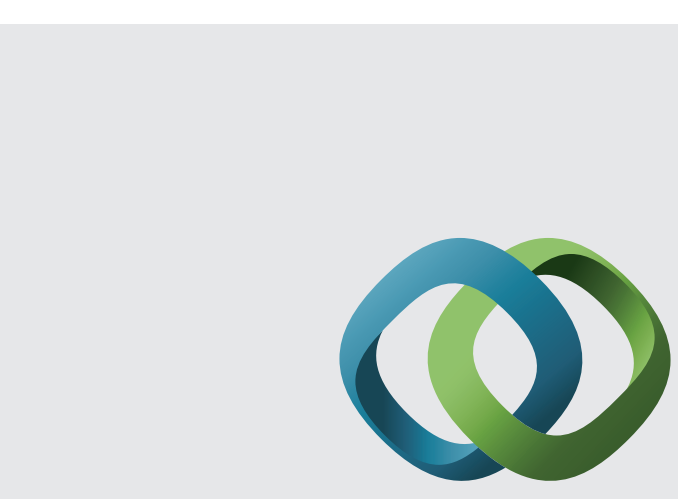

\section{Hindawi}

Submit your manuscripts at

http://www.hindawi.com
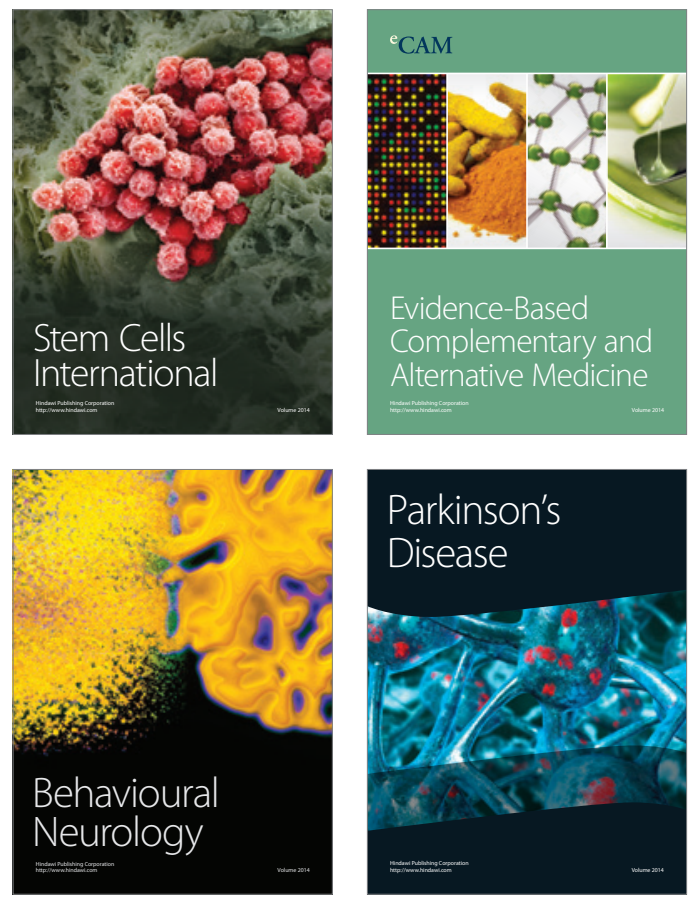
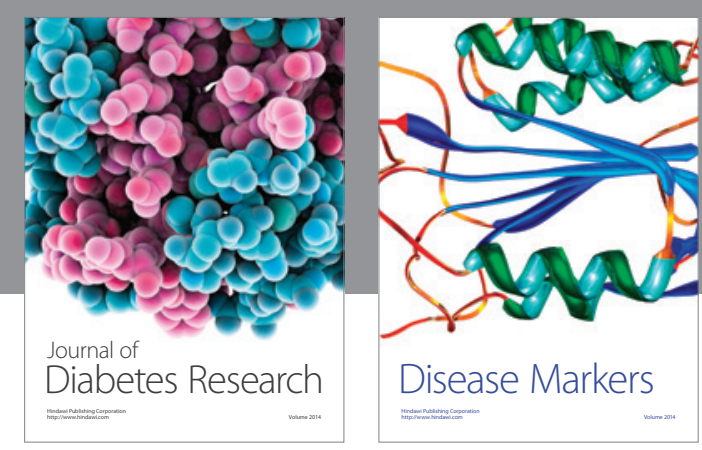

Disease Markers
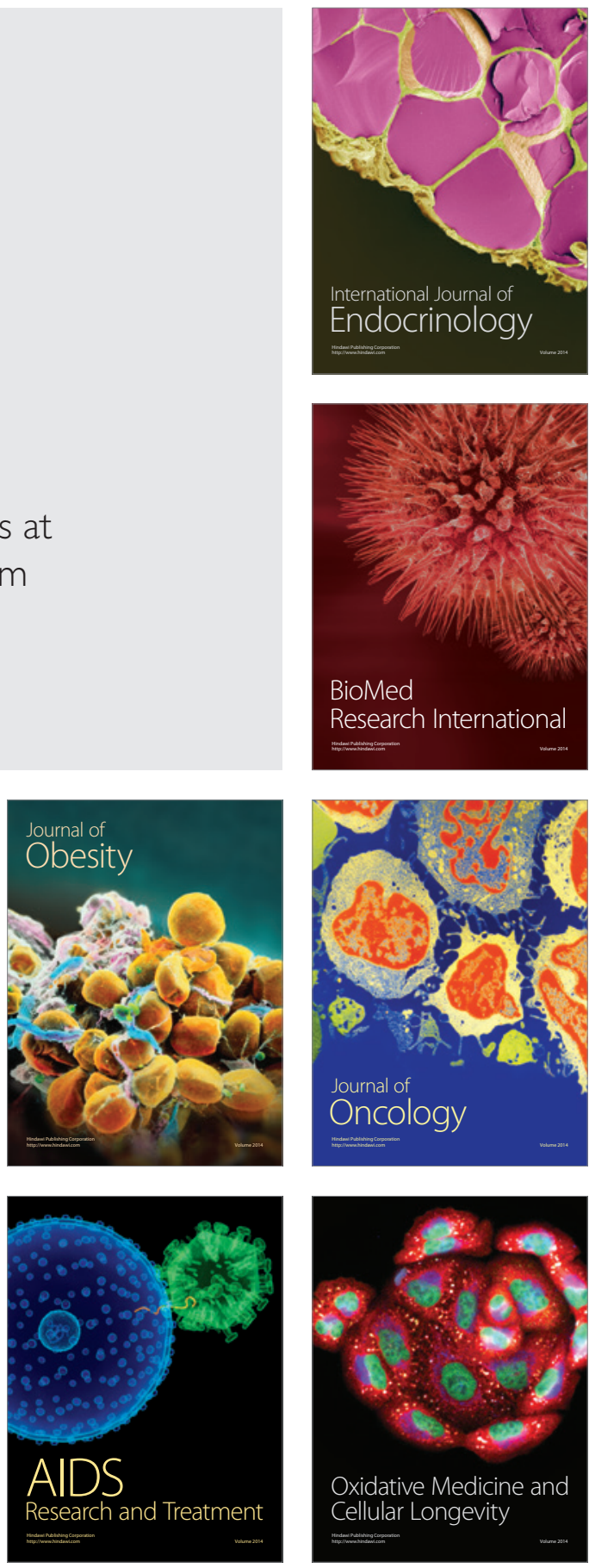